\title{
Statistical Investigations to Milk Yield Data of Jersey and Holstein Friesian Cross Breeds
}

\author{
Radhika Thakur*, R.K. Gupta and P.K. Mahajan \\ Department of Basic Sciences, College of Forestry, Dr. Y. S. Parmar University of \\ Horticulture and Forestry Nauni- Solan, Himachal Pradesh-173230, India \\ *Corresponding author
}

\begin{abstract}
A B S T R A C T
Keywords

Milk Yield, Jersey

Cross, Holstein

Friesian Cross, Chi-

square test, Stability

Analysis

Article Info

Accepted:

15 February 2019

Available Online:

10 March 2019

Monthly data of 4 cows of Jersey and 4 cows of Holstein Friesian crossbred cows on milk yield of seven lactations and for different months were analyzed for the present study which were collected from Dairy Farm of Dr. Yashwant Singh Parmar University of Horticulture and Forestry NauniSolan, Himachal Pradesh. Different variability parameters were estimated separately for both cross breeds and also the stability analysis was carried out to study the performance of different lactations and months with respect to milk yield. Data on milk yield for different months were analyzed separately and pooled analyses of variance were performed.
\end{abstract}

\section{Introduction}

Dairying has contributed significantly to the overall growth of agriculture sector. Dairying has an acknowledged role to play in the socioeconomic transformation and sustainable rural development in India. In dairy industry, milk production provides a great contribution to the national as well as nourishment of people throughout the world. In the milk manufacturing process, one of the most important aspects of dairy production is the modeling of the milk yield and quality (Beever et al., 1991).The Indian dairy industry has shown substantial growth since the eighth plan onwards and the milk output has not only placed the industry first in the world, but also represents sustained growth in availability of milk and milk products.

India holds the distinction of the highest milk production in the world. Holstein and Jersey are the most important dairy breeds of cattle known for their high milk yield and quality. Holstein cross, the primary dairy breed has its origin in Holland. After the Holstein, the Jersey is the second most popular specialist dairy breed in the world and has originated 
from Jersey, the largest Island. These breeds are intensively used in India for crossbreeding purpose.

\section{Materials and Methods}

In the present study, secondary data on milk yield for thirty seven years from 1978-2014 month wise, lactation wise for the Jersey and Holstein Friesian crossbred cows were taken from dairy farm of Department of Silviculture and Agroforestry, Dr. Yashwant Singh Parmar University of Horticulture and Forestry, Nauni, Solan, Himachal Pradesh.

\section{Variability analysis}

In order to compare the consistency, the coefficient of variation of milk yield of Jersey and Holstein Friesian crossbred cows has been worked out for each lactation (lactation 1 to lactation 7) and for each month, as given below:

$\mathrm{CV}=\frac{\sigma}{\mathrm{x}} \times 100$

where,

$\overline{\mathrm{X}}($ Arithematic Mean $)=\frac{1}{\mathrm{n}} \sum_{\mathrm{i}=1}^{\mathrm{n}} \mathrm{X}_{\mathrm{i}}$

$\sigma($ Standard Deviation $)=\sqrt{\left[\frac{1}{\mathrm{n}} \sum_{\mathrm{i}=1}^{\mathrm{n}}\left(\mathrm{x}_{\mathrm{i}}-\overline{\mathrm{X}}\right)^{2}\right]}$

In the present study, others parameters of variability analysis viz. standard error, range, fudicial limits, CV were also calculated.

\section{Bartlett's Chi-square test for homogeneity} of several independent estimates of the population variances

Bartlett's Chi-square test for homogeneity of variances among different lactations/months was applied to test whether two or more independent samples are drawn from the population having same variances or not.

Null hypothesis, $\mathrm{H}_{0}: \sigma_{1}^{2}=\sigma_{2}^{2}=\cdots=\sigma_{\mathrm{k}}^{2}$

Alternate hypothesis, $\mathrm{H}_{1}$ ssome of the independent estimates have different variances.

Suppose there are k-independent samples of sizes $\mathrm{n}_{1}, \mathrm{n}_{2}, \ldots, \mathrm{n}_{\mathrm{k}}$ with sample variance $\mathrm{s}_{1}^{2}, \mathrm{~s}_{2}^{2}, \ldots, \mathrm{s}_{\mathrm{k}}^{2}$ respectively.

where,

$s_{i}^{2}=\frac{1}{n_{i}-1} \sum_{j=1}^{n_{i}}\left(X_{i j}-\bar{X}_{i}\right)^{2},(i=1,2, \ldots, k) \quad$ be the unbiased estimate of the population variance, obtained from the $i^{\text {th }}$ sample $X_{i j}$, $\left(\mathrm{j}=1,2, \ldots, \mathrm{n}_{\mathrm{i}}\right)$ and based on $v_{\mathrm{i}}=\left(\mathrm{n}_{\mathrm{i}}-1\right)$ d.f., all the $\mathrm{k}$ samples being independent.

Under the null hypothesis that the samples were collected from the same population with variance $\sigma^{2}$, i.e., the independent estimates $\mathrm{s}_{\mathrm{i}}^{2},(\mathrm{i}=1,2, \ldots, \mathrm{k})$ of $\sigma^{2}$ are homogeneous, Bartlett proved that the statistic:

$\chi^{2}=\frac{\sum_{\mathrm{i}=1}^{\mathrm{k}}\left(v_{\mathrm{i}} \log _{\mathrm{e}} \frac{\mathrm{s}^{2}}{\mathrm{~s}_{\mathrm{i}}^{2}}\right)}{\left[1+\frac{1}{3(\mathrm{k}-1)}\left\{\sum_{\mathrm{i}}\left(\frac{1}{v_{\mathrm{i}}}\right)-\frac{1}{v}\right\}\right]}$

where, $s^{2}=\frac{\sum v_{i} \varepsilon_{i}^{2}}{\sum v_{i}}$

Follows Chi-square distribution with $(\mathrm{k}-1)$ degrees of freedom.

\section{Results and Discussion}

Variability analysis among lactations/months

Monthly data of 4 cows of Jersey and 4 cows of Holstein Friesian crossbred cows on milk yield of seven lactations viz. lactation 1, lactation 2, lactation 3, lactation 4, lactation 5, lactation 6 and lactation 7 were analyzed for 
the present study which were collected from Dairy Farm of Dr. Yashwant Singh Parmar University of Horticulture and Forestry NauniSolan, Himachal Pradesh and also month wise data were collected and different variability parameters viz. mean milk yield, standard error, fudicial limit and coefficient of variation were estimated separately for both breeds i.e. Jersey and Holstein Friesian crossbred cows and Chi- square test were also applied (Laben, 1963; Murdia and Tripathi, 1991; Lovendahl and Chagunda, 2011; Jingar et al., 2014; Adebayo and Oseni, 2016).

Variability analysis for milk yield (litres) among lactations

Variability analysis for milk yield (litres) among lactations of Jersey crossbred cows

Table 1 presents mean, standard error, fudicial limit and coefficient of variation for seven lactations for Jersey crossbred cows. Table 1 reveals that mean milk yield of Jersey crossbred cows was maximum during lactation 4 followed by lactation 5 , lactation 6 , lactation 3, lactation 7, lactation 2 and lactation 1 with values 2729.88, 2635.75, $2440.38,2370.63,2347.13,2254.25$ and 2010.38 litres per lactation with standard error of $123.87,283.11,114.17,75.77,213.99$, 125.74 and 105.85 respectively. Fudicial limits for the respective lactations were 2480.69-2979.06 litres, 2066.21-3205.29 litres, 2210.69-2670.06 litres, 2218.202523.05 litres, 1916.63-2777.62 litres, 2001.28-2507.22 litres and 1797.43-2223.32 litres. The mean milk yield of all seven lactations was 2398.34 (litres) with standard error of 72.82. Coefficient of variation (CV) for milk yield was minimum in lactation 3 (6.39 per cent) followed by lactation 4, lactation 6, lactation 1, lactation 2, lactation 7 and lactation 5 with values i.e., 6.39, 9.07, $9.36,10.53,11.16,18.23$ and 21.48 per cent, respectively. Coefficient of variation (CV) for milk yield among all seven lactations of Jersey crossbred cows was found to be 6.07 per cent.

Variability analysis for milk yield (litres) among lactations of Holstein Friesian crossbred cows

Table 2 presents mean, standard error, fudicial limit and coefficient of variation for seven lactations for Holstein Friesian crossbred cows. Table 2 reveals that mean milk yield of Holstein Friesian crossbred cows was maximum during lactation 4 followed by lactation 5, lactation 6, lactation 3, lactation 7, lactation 2 and lactation 1 with values 2966.00, 2914.13, 2884.75, 2848.50, 2785.38, 2578.38 and 2295.88 litres per lactation with standard error of 59.68, 281.47, 369.33, 88.83, $81.00,209.32$ and 34.59 respectively. Fudicial limits for the respective lactations were 2845.94-3086.06 litres, 2347.87-3480.38 litres, 2141.76-3627.74 litres, 2669.803027.20 litres, 2622.42-2948.33 litres, 2157.28-2999.47 litres and 2226.29-2365.46 litres. The mean milk yield of all seven lactations was 2753.29 (litres) with standard error of 127.87. Coefficient of variation (CV) for milk yield was minimum in lactation 1 (3.01 per cent) followed by lactation 4, lactation 7, lactation 3, lactation 2, lactation 5 and lactation 6 with values i.e., 4.02, 5.82, $6.24,16.24,19.32$ and 25.61 per cent respectively. Coefficient of variation (CV) for milk yield among all seven lactations of Holstein Friesian crossbred cows was found to be 9.29 per cent.

Comparison with respect to variability for milk yield (litres) among lactations

Comparison with respect to variability for milk yield (litres) among lactations of Jersey crossbred cows

Bartlett's Chi-square test was applied for testing the homogeneity of variances among 
seven lactations with respect to milk yield. Table 3 reveals that variance in milk yield of Jersey crossbred cows in descending order was lactation 5, lactation 6, lactation 3, lactation 7, lactation 4, lactation 2 and lactation 1 with the values being 12924.91, 12638.80, 11471.01, 11426.11, 11163.42, 9822.58 and 8802.63 litres per lactation respectively. The maximum variation in milk yield of Jersey crossbred cows was in lactation 5 and minimum variation in lactation 1.

Bartlett's Chi-square test was applied to test the homogeneity of variances among seven lactations for milk yield of Jersey crossbred cows and Chi- square calculated value was tested against Chi-square table value at 5\% level of significance with 6 degree of freedom.

Table 3 reveals that in case of Jersey crossbred cows, Bartlett's Chi-square calculated value for milk yield was 60.71 , which was less than with Chi-square table value (12.59) at 5\% level of significance at 6 degree of freedom, indicated that different lactations had heterogeneous variance. Variability in milk yield showed that there was significant variation among seven lactations with respect to milk yield.

\section{Comparison with respect to variability for milk yield (litres) among lactations of} Holstein Friesian crossbred cows

Table 4 reveals that variance in milk yield of Holstein Friesian crossbred cows in descending order was lactation 5, lactation 6 , lactation 3, lactation 4, lactation 7, lactation 1 and lactation 2 with values 17745.07, 16084.58, 13029.72, 12731.70, 12356.76, 11591.12 and 11320.74 litres per lactation respectively. The maximum variation in milk yield of Holstein Friesian crossbred cows was found in lactation 5 and minimum variation in lactation 2. Bartlett's Chi-square test was applied to test the homogeneity of variances among seven lactations for milk yield of Holstein Friesian crossbred cows and Chisquare calculated value was tested against Chi-square table value at $5 \%$ level of significance with 6 degree of freedom.

Table 4 reveals that in case of Holstein Friesian crossbred cows, Bartlett's Chi-square calculated value for milk yield was 63.71, which was also more than Chi-square table value (12.59) at 5\% level of significance at 6 degree of freedom which showed that there was significant difference for variance among seven lactations with respect to milk yield.

\section{Variability analysis for milk yield (litres) among different months}

Variability analysis for milk yield (litres) among different months of Jersey crossbred cows

Table 5 presents mean, standard error, fudicial limit and coefficient of variation of milk yield for different months from January to December. Table 5 reveals that mean milk yield of Jersey crossbred cows was maximum in July month followed by months June, May, August, September, October, April, March, January, December, February and November, i.e., 247.79 litres, 247.66 litres, 225.70 litres, 221.89 litres, 215.59 litres, 197.34 litres, 188.38 litres, 180.84 litres, 179.50 litres, 173.55 litres, 160.84 litres and 159.27 litres per month with values of standard errors $17.91,19.87,23.33,18.85,12.44,15.75$, $22.95,23.56,19.91,19.60,20.23$ and 18.08, respectively.

Fudicial limits for the respective months were 211.03-284.54 litres, 206.89-288.43 litres, 177.82-273.57 litres, 183.21-260.58 litres, 190.06-241.12 litres, 165.02-229.66 litres, 141.28-235.47 litres, 132.50-229.18 litres, 138.64-220.36 litres, 133.33-213.78 litres, 119.33-202.34 litres and 122.16-196.37 litres. 
The mean milk yield of all months was 199.86 litres with standard error 5.76. Coefficient of variation $(\mathrm{CV})$ for milk yield was minimum in September month followed by July, October, June, August, May, January, December, November, April, February and March with values i.e., 30.54, 38.26, 42.24, 42.45, 44.96, $54.71,58.70,59.77,60.08,64.47,66.55$ and 68.93 per cent, respectively. Coefficient of variation (CV) for milk yield among all months of Jersey crossbred cows was found as 15.26 per cent.

Variability analysis for milk yield (litres) among different months of Holstein Friesian crossbred cows

Table 6 presents mean, standard error, fudicial limit and coefficient of variation of milk yield for different months from January to December. Table 6 reveals that mean milk yield of Holstein Friesian crossbred cows was maximum in November month followed by December, April, January, May, August, March, July, February, October, June and September with values as292.88, 278.88, $247.84, \quad 247.34, \quad 246.73, \quad 227.88, \quad 226.20$, 224.98, 204.41, 197.16, 192.07 and 188.54 litres per month with values of standard errors $26.44,19.20,17.94,17.26,22.26,21.07$, $19.02,24.21,21.42,25.56,18.91$ and 23.45 litres. Fudicial limits for the respective months were 238.62-347.13 litres, 239.48-318.27 litres, 211.02-284.66 litres, 211.93-282.75 litres, 201.05-292.41 litres, 184.63-271.12 litres, 187.18-265.22 litres, 175.31-274.65 litres, 160.46-248.36 litres, 144.72-249.60 litres, 153.27-230.87 litres and 140.41-236.66 litres. The mean milk yield of all months was 231.24 litres with standard error 6.14.

Coefficient of variation (CV) for milk yield was minimum in December month followed by January, April, March, May, November, August, June, February, July, September and October with values i.e., 36.43, 36.92, 38.31,
$44.49, \quad 47.75,47.78,48.94,52.10,55.45$, $56.93,65.83$ and 68.59 per cent, respectively. Coefficient of variation (CV) for milk yield among all months of Holstein Friesian crossbred cows was found 14.05 per cent.

Comparison with respect to variability for milk yield (litres) among different months

Comparison with respect to variability for milk yield (litres) among different months of Jersey crossbred cows

Bartlett's Chi-square test was applied for testing the homogeneity of variances among different months of Jersey crossbred cows with respect to milk yield. Table 7 reveals that variation in milk yield of Jersey crossbred cows in descending order was months March, May, April, February, January, June, December, August, November, July, October and September with the values 15539.85, $15245.19, \quad 14750.77,11456.98,11101.93$, 11053.46, 10761.67, 9952.53, 9156.16, 8986.21, 6946.76 and 4334.00 litres per month respectively. The maximum variation in milk yield of Jersey crossbred cows was analyzed in March month and minimum variation in September month.

Bartlett's Chi-square test was applied to test the homogeneity of variances among different months of Jersey crossbred cows for milk yield and Chi- square calculated value was tested against Chi-square table value at 5\% level of significance with 11 degree of freedom. Table 7 reveals that in case of Jersey crossbred cows, Bartlett's Chi-square calculated value for milk yield was 79.86 which was more than Chi-square table value (19.68) at 5\% level of significance at 11 degree of freedom indicated that different months had heterogeneous variances. Variability in milk yield showed that there was highly significant variation among different months with respect to milk yield. 
Comparison with respect to variability for milk yield (litres) among different months of Holstein Friesian crossbred cows

Bartlett's Chi-square test was applied for testing the homogeneity of variances among different months of Holstein Friesian crossbred cows with respect to milk yield.

Table 8 reveals that variation in milk yield of Holstein Friesian crossbred cows was months November, October, July, September, May, February, August, December, March, June, April and January with values i.e., 19578.51, 18287.46, 16407.40, 15403.63, 13877.77,
12847.50, 12435.23, 10323.97, 10125.54, 10013.77, 9014.78 and 8339.09 litres per month respectively. The maximum variation in milk yield of Holstein Friesian crossbred cows was found in November month and minimum in January month.

Bartlett's Chi-square test was applied to test the homogeneity of variances among different months of Holstein Friesian crossbred cows for milk yield and Chi- square calculated value was tested against Chi-square table value at 5\% level of significance with 11 degree of freedom.

Table.1 Variability analysis for milk yield (litres) of Jersey crossbred cows during different lactations

\begin{tabular}{|c|c|c|c|c|c|}
\hline Lactation(s) & $\begin{array}{c}\text { Mean } \\
\text { (litres) }\end{array}$ & Range & SE & Fudicial Limit & CV (\%) \\
\hline Lactation 1 & 2010.38 & $1803.00-2291.00$ & 105.85 & $1797.43-2223.32$ & 10.53 \\
\hline Lactation 2 & 2254.25 & $1986.00-2512.50$ & 125.74 & $2001.28-2507.22$ & 11.16 \\
\hline Lactation 3 & 2370.63 & $2148.50-2486.00$ & 75.77 & $2218.20-2523.05$ & 6.39 \\
\hline Lactation 4 & 2729.88 & $2389.50-2960.50$ & 123.87 & $2480.69-2979.06$ & 9.07 \\
\hline Lactation 5 & 2635.75 & $1879.50-3237.50$ & 283.11 & $2066.21-3205.29$ & 21.48 \\
\hline Lactation 6 & 2440.38 & $2160.50-2703.00$ & 114.17 & $2210.69-2670.06$ & 9.36 \\
\hline Lactation 7 & 2347.13 & $1863.50-2767.00$ & 213.99 & $1916.63-2777.62$ & 18.23 \\
\hline Overall & 2398.34 & $1803.00-3237.50$ & 72.82 & $2251.84-2544.84$ & 6.07 \\
\hline
\end{tabular}

Table.2 Variability analysis for milk yield (litres) of Holstein Friesian crossbred cows during different lactations

\begin{tabular}{|c|c|c|c|c|c|}
\hline Lactation(s) & $\begin{array}{c}\text { Mean } \\
\text { (litres) }\end{array}$ & Range & SE & Fudicial Limit & CV (\%) \\
\hline Lactation 1 & 2295.88 & $2227.00-2392.00$ & 34.59 & $2226.29-2365.46$ & 3.01 \\
\hline Lactation 2 & 2578.38 & $2144.00-3074.50$ & 209.32 & $2157.28-2999.47$ & 16.24 \\
\hline Lactation 3 & 2848.50 & $2648.50-3080.00$ & 88.83 & $2669.80-3027.20$ & 6.24 \\
\hline Lactation 4 & 2966.00 & $2825.50-3110.50$ & 59.68 & $2845.94-3086.06$ & 4.02 \\
\hline Lactation 5 & 2914.13 & $2219.00-3462.00$ & 281.47 & $2347.87-3480.38$ & 19.32 \\
\hline Lactation 6 & 2884.75 & $2015.50-3807.50$ & 369.33 & $2141.76-3627.74$ & 25.61 \\
\hline Lactation 7 & 2785.38 & $2573.50-2933.50$ & 81.00 & $2622.42-2948.33$ & 5.82 \\
\hline Overall & 2753.29 & $2015.50-3807.50$ & 127.87 & $2496.05-3010.52$ & 9.29 \\
\hline
\end{tabular}


Table.3 Lactation wise comparisons of Jersey crossbred cows with respect to variance of milk yield (litres)

\begin{tabular}{|c|c|}
\hline Lactation(s) & Variance \\
\hline Lactation 1 & 8802.63 \\
\hline Lactation 2 & 9822.58 \\
\hline Lactation 3 & 11471.01 \\
\hline Lactation 4 & 11163.42 \\
\hline Lactation 5 & 12924.91 \\
\hline Lactation 6 & 12638.80 \\
\hline Lactation 7 & 11426.11 \\
\hline$x_{\text {cal }}^{2}$ & 60.71 \\
\hline$x_{0.05}^{2}(\mathbf{6})$ & 12.59 \\
\hline
\end{tabular}

Table.4 Lactation wise comparisons of Holstein Friesian crossbred cows with respect to variance of milk yield (litres)

\begin{tabular}{|c|c|}
\hline Lactation(s) & Variance \\
\hline Lactation 1 & 11591.12 \\
\hline Lactation 2 & 11320.74 \\
\hline Lactation 3 & 13029.72 \\
\hline Lactation 4 & 12731.7 \\
\hline Lactation 5 & 17745.07 \\
\hline Lactation 6 & 16084.58 \\
\hline Lactation 7 & 12356.76 \\
\hline$x_{\text {cah }}^{2}$ & 63.71 \\
\hline$x_{0.05}^{2}(6)$ & 12.59 \\
\hline
\end{tabular}

Table.5 Variability analysis for milk yield (litres) of Jersey crossbred cows during different months

\begin{tabular}{|c|c|c|c|c|c|}
\hline Month(s) & Mean (litres) & Range & SE & Fudicial Limit & CV (\%) \\
\hline January & 179.50 & $4.00-397.50$ & 19.91 & $138.64-220.36$ & 58.70 \\
\hline February & 160.84 & $1.00-315.00$ & 20.23 & $119.33-202.34$ & 66.55 \\
\hline March & 180.84 & $22.50-368.50$ & 23.56 & $132.50-229.18$ & 68.93 \\
\hline April & 188.38 & $38.50-3520.00$ & 22.95 & $141.28-235.47$ & 64.47 \\
\hline May & 225.70 & $32.00-410.50$ & 23.33 & $177.82-273.57$ & 54.71 \\
\hline June & 247.66 & $158.50-439.00$ & 19.87 & $206.89-288.43$ & 42.45 \\
\hline July & 247.79 & $46.50-414.50$ & 17.91 & $211.03-284.54$ & 38.26 \\
\hline August & 221.89 & $98.00-378.50$ & 18.85 & $183.21-260.58$ & 44.96 \\
\hline September & 215.59 & $123.50-342.00$ & 12.44 & $190.06-241.12$ & 30.54 \\
\hline October & 197.34 & $58.50-380.50$ & 15.75 & $165.02-229.66$ & 42.24 \\
\hline November & 159.27 & $15.00-328.00$ & 18.08 & $122.16-196.37$ & 60.08 \\
\hline December & 173.55 & $15.50-339.50$ & 19.60 & $133.33-213.78$ & 59.77 \\
\hline Overall Mean & 199.86 & $1.00-439.00$ & 5.76 & $188.04-211.69$ & 15.26 \\
\hline
\end{tabular}


Table.6 Variability analysis for milk yield (litres) of Holstein Friesian crossbred cows during different months

\begin{tabular}{|c|c|c|c|c|c|}
\hline Month(s) & $\begin{array}{c}\text { Mean } \\
\text { (litres) }\end{array}$ & Range & SE & Fudicial Limit & CV (\%) \\
\hline January & 247.34 & $41.50-413.00$ & 17.26 & $211.93-282.75$ & 36.92 \\
\hline February & 204.41 & $9.00-392.50$ & 21.42 & $160.46-248.36$ & 55.45 \\
\hline March & 226.20 & $34.00-397.00$ & 19.02 & $187.18-265.22$ & 44.49 \\
\hline April & 247.84 & $96.00-445.00$ & 17.94 & $211.02-284.66$ & 38.31 \\
\hline May & 246.73 & $8.50-396.50$ & 22.26 & $201.05-292.41$ & 47.75 \\
\hline June & 192.07 & $49.00-322.00$ & 18.91 & $153.27-230.87$ & 52.10 \\
\hline July & 224.98 & $8.00-447.50$ & 24.21 & $175.31-274.65$ & 56.93 \\
\hline August & 227.88 & $113.00-432.00$ & 21.07 & $184.63-271.12$ & 48.94 \\
\hline September & 188.54 & $3.00-451.00$ & 23.45 & $140.41-236.66$ & 65.83 \\
\hline October & 197.16 & $14.00-426.50$ & 25.56 & $144.72-249.60$ & 68.59 \\
\hline November & 292.88 & $96.50-521.50$ & 26.44 & $238.62-347.13$ & 47.78 \\
\hline December & 278.88 & $157.50-459.00$ & 19.20 & $239.48-318.27$ & 36.43 \\
\hline Overall Mean & 231.24 & $3.00-521.50$ & 6.14 & $218.64-243.84$ & 14.05 \\
\hline
\end{tabular}

Table.7 Month wise comparisons of Jersey crossbred cows with respect to variance of milk yield (litres)

\begin{tabular}{|c|c|}
\hline Month(s) & Variance \\
\hline January & 11101.93 \\
\hline February & 11456.98 \\
\hline March & 15539.85 \\
\hline April & 14750.77 \\
\hline May & 15245.19 \\
\hline June & 11053.46 \\
\hline July & 8986.21 \\
\hline August & 9952.53 \\
\hline September & 4334.00 \\
\hline October & 6946.76 \\
\hline November & 9156.16 \\
\hline December & 10761.67 \\
\hline$x_{c a R}^{2}$ & 79.86 \\
\hline$x_{0.05}^{2}(11)$ & 19.68 \\
\hline
\end{tabular}


Table.8 Month wise comparisons of Holstein Friesian crossbred cows with respect to variance of milk yield (litres)

\begin{tabular}{|c|c|}
\hline Month(s) & Variance \\
\hline January & 8339.09 \\
\hline February & 12847.50 \\
\hline March & 10125.54 \\
\hline April & 9014.78 \\
\hline May & 13877.77 \\
\hline June & 10013.77 \\
\hline July & 16407.40 \\
\hline August & 12435.23 \\
\hline September & 15403.63 \\
\hline October & 18287.46 \\
\hline November & 19578.51 \\
\hline December & 10323.97 \\
\hline$x_{G \infty}^{2}$ & 77.92 \\
\hline$x_{0.05}^{2}(11)$ & 19.68 \\
\hline
\end{tabular}

Table 8 reveals that in case of Holstein Friesian crossbred cows, Bartlett's Chi-square calculated value for milk yield was 77.92, which was also more than Chi-square table value (19.68) at 5\% level of significance at 11 degree of freedom which showed that there was also highly significant difference for variance among different months with respect to milk yield.

37 years secondary data on milk yield of Jersey and Holstein Friesian crossbred cows were collected for seven lactations/months i.e. lactation 1 to lactation 7/ January to December. The data were subjected to variability analysis with respect to milk yield in order to test the variability among seven lactations/different months of both crossbred cows. Different variability parameters were used for standard error of mean, range, fudicial limits, coefficient of variation and variance. The homogeneity of variances among lactations/ different months were tested by Bartlett's Chi- square test which suggested that there were significant variability with respect to milk yield among seven lactations/different months in both crossbred cows. Maximum mean milk yield of Jersey and Holstein Friesian crossbred cows were obtained in lactation 4and minimum in lactation 1 , while coefficient of variation ranges from 6.39 to 21.48 per cent and 3.01 to 25.61 per cent. During different months, the maximum monthly mean milk yield of Jersey crossbred cows was observed in July month and minimum in November month. Coefficient of variation ranges from 30.54 to 68.93 percent and 36.43 to 68.59 per cent. Bartlett's Chi- square test suggested that there were significant difference for variability among seven lactations/different months with respect to milk yield for both crossbred cows.

\section{References}

Adebayo A A and Oseni S O. 2016. Evaluation of the milk yield performance of Jersey cows under tropical climate conditions in Nigeria. Livestock Research for Rural Development, 28(10): 1-5. 
Beever D E, Rook A J, France J, Dhanoa M S and Gill M. 1991. Review of empirical and mechanistic models of lactation performance by the dairy cow. Livestock Production Science, 29: 115130.

Jingar S, Mehla R K, Singh M and Roy A K. 2014. Lactation curve pattern and prediction of milk production performance in crossbred cows. Journal of Veterinary Medicine, pp 1-6.

Laben R C.1963. Factors responsible for variation in milk composition. Journal of Dairy Science, 46(11): 1293-1301.

Lovendahl P and Chagunda M G G. 2011. Covariance among milking frequency, milk yield and milk composition from automatically milked cows. Journal of Dairy science, 94(11): 5381-5392.

Murdia C K and Tripathi V N. 1991. Factors affecting performance traits in Jersey cattle in India. Indian Veterinary Journal, 68: 1129-1142.

\section{How to cite this article:}

Radhika Thakur, R.K. Gupta and Mahajan, P.K. 2019. Statistical Investigations to Milk Yield Data of Jersey and Holstein Friesian Cross Breeds. Int.J.Curr.Microbiol.App.Sci. 8(03): 20562065. doi: https://doi.org/10.20546/ijcmas.2019.803.245 